UDK 78(438)"16"

Barbara Przybyszewska-Jarmińska

Institut der Kunst der Polnischen Akademie der Wissenschaften, Warschau

Umetnostni inštitut Poljske akademije znanosti, Varšava

\title{
The Polish Contribution to Central European Musical Culture in the Seventeenth Century. The Case of Marcin Mielczewski
}

\section{Poljski prispevek k srednjeevropski glasbeni kulturi v sedemnajstem stoletju. Primer Marcina Mielczewskega}

SUMMARY

The seventeenth-century Commonwealth of Poland and Lithuania, embracing the lands of the Polish Crown (together with the territory of present-day Ukraine) and the Grand Duchy of Lithuania, belonged geographically to both Central and Eastern Europe. It was a multiethnic and multiconfessional state, in which the Latin and Greek cultures were mutually interactive. With regard to the musical culture of the royal court, however, it was the close ties with Italy that were of the greatest significance.

The Polish kings of the Vasa dynasty (above all Zygmunt III and Władysław IV) maintained music chapels consisting to a considerable extent of Italian musicians, among whom were Luca Marenzio, Giulio Cesare Gabussi, Asprilio Pacelli, Giovanni Francesco Anerio and Tarquinio Merula. Thanks to the Polish patronage, they not only composed new works, but also trained musicians of various nations belonging to the royal ensembles. Among the composers trained at the Polish court was the Italian Marco Scacchi (d. 1662), chapel-master to Władysław IV, the composer of operas staged in the royal theatre, and also a music theorist - the author of a clas-
PovzeTEK

Poljsko-litovski commonwealth sedemnajstega stoletja, v katerem so bile združene posesti poljske krone (skupaj z ozemljem današnje Ukrajine) in velike poljske vojvodine Litve, je geografsko pripadal tako $\mathrm{k}$ Srednji kot tudi $\mathrm{k}$ Vzhodni Evropi. To je bila multietnična in multikonfesionalna država, kjer sta se prežemali latinska in grška kultura. Za glasbo na cesarskem dvoru pa so bile najpomembnejše tesne vezi $z$ Italijo.

Poljski kralji dinastije Vasa (zlasti Zigmunt III in Vladislav IV) so ohranjali glasbene kapele, v katerih je bil velik delež italijanskih glasbenikov, med katerimi so bili Luca Marenzio, Giulio Cesare Gabussi, Asprilio Pacelli, Giovanni Francesco Anerio in Tarquinio Merula. Zahvaljujoč poljskemu patronatu niso komponirali samo novih del, temveč so tudi poučevali glasbenike različnih narodnosti, ki so bili udeleženi v dvornih ansamblih. Med skladatelji, ki so se učili na poljskem dvoru, je bil Italijan Marco Scacchi (umrl 1662), kapelnik Vladislava IV, skladatelj oper, ki so jih uprizorili dvornem gledališču, in teoretik, ki je klasificiral glasbene zvrsti v razpravi o glasbeni teoriji z gdanškim organistom 
MUZIKOLOŠKI ZBORNIK - MUSICOLOGICAL ANNUAL XL

sification of musical genres which was produced during Scacchi's dispute over music theory with the Gdańsk organist Paul Siefert. This dispute contributed to the popularisation across Europe of the works of Scacchi and also of other musicians associated with the court of the Polish Vasas. Extant handwritten sources of Silesian provenance (belonging to the Emil Bohn collection, currently held in the Staatsbibliothek Preussischer Kulturbesitz in Berlin) testify the considerable interest in this region (now within the Polish borders, but in the seventeenth century constituting a dominion of the Empire) in the religious compositions of Marcin Mielczewski (d. 1651), musician to Władysław IV (until 1644) and subsequently, until his death, chapel-master to Karol Ferdinand Vasa, Bishop of Płock and Wrocław. Of Mielczewski's compositional output for the needs of the Roman Catholic Church, copyists from Lutheran circles in Wrocław chose primarily psalms that were universal to the Christian repertory, furnishing those works whose texts chimed with the doctrine of the Augsburg confession with more appropriate texts of German-language contrafacta. However, this method was not always successful in eliminating traces of Catholicism, which remained, for example, in the melodies of works based on pre-compositional material drawn by Mielczewski from Marian songs that were popular in Poland (e.g. the church concerto Audite gentes et exsultate, also preserved in a version with the text of a German-language contrafactum entitled Nun höret alle, based on the song O gloriosa Domina, which in the former Commonwealth was treated as a chivalrous hymn).
Paulom Siefertom. Ta razprava je pomagala $\mathrm{k}$ popularizaciji tako Scacchijeve glasbe kot tudi glasbe $s$ poljskega dvora Vasa po Evropi. Ohranjeni rokopisi šlezijske provenience (iz zbirke Emila Bohna, ki se trenutno nahaja v berlinski Staatsbibliothek Preussischer Kulturbesitz) pričajo o pomembnem interesu v regiji (danes znotraj poljskih meja, a v sedemnajstem stoletju del cesarstva) za religiozno kompozicijo Marcina Mielczewskega (umrl 1651), glasbenika Vladislava IV (do 1644) in nadalje, do njegove smrti, kapelnika Karol Ferdinand Vasa, nadškofa Płocka in Wrocława. Iz kompozicijske zapuščine Mielczewskega za potrebe rimokatoliškega bogoslužja so prepisovalci luteranskih krogov v Wrocławu izbrali predvsem psalme, ki so bili univerzalni v krščanskem repertoriju, opremljali ta dela, katerih besedila so se bolj ujemala $\mathrm{z}$ doktrino avgsburške veroizpovedi, z bolj ustreznimi besedili nemških kontrafaktov. Vendar se ta metoda ni vedno obnesla pri brisanju sledov katolicizma, ki je ostal, na primer, $\mathrm{v}$ melodijah iz del Mielczewskega po na poljskem priljubljenih Marijinih pesmi (npr. cerkveni koncert Audite gentes et exsultate, ohranjen tudi v verziji z besedilom nemškega kontrafakta Nun höret alle, zasnovanega na pesmi O gloriosa Domina, ki so ga nekdanjem commonwealthu šteli za viteško himno).

The vast territory of the Commonwelth of Poland and Lithuania towards the end of the sixteenth century and during the first half of the seventeenth century was situated geographically both in central Europe (most of the lands of present-day Poland) and eastern Europe (a substantial part of the Grand Duchy of Lithuania, i.e. what is now Belarus, Lithuania and Latvia, as well as the south-eastern lands of the Polish Crown, approximately encompassing the territory of present-day Ukraine). In the increasingly widely used, although still controversial, terminology employed with regard to the division of the continent based on political and cultural criteria, this area is defined as centraleastern Europe ${ }^{1}$. This term is appropriate with regard to the multiethnic and

${ }^{1}$ See Historia Europy Środkowo-Wschodniej [The History of East Central Europe], vol. 1, ed. Jerzy Kłoczowski, Lublin 2000, p. 7-20. 
multiconfessional composition of the communities inhabiting the area in the seventeenth century. Although the Polish-Lithuanian state of that time was home to the followers of a variety of religions (including Judaism and Islam), particularly crucial was the coexistence of the different Christian confessions (Roman Catholicism, Orthodox, and Protestant - Lutheran, Calvinist, Mennonite, Antitrinitarian $^{2}$ ). The Commonwelth thus constituted a combination of West and East, of the Latin and Greek cultures. However, if we focus our attention on artistic culture, and especially on the culture of the royal court, regardless of where it was located at a particular time (Cracow, Warsaw, Vilnius, Lviv or elsewhere), we can observe its strong ties to the main centres of central Europe at that time - Graz and Vienna, Prague, Wrocław and Munich. Moreover, Latin culture became increasingly influential, especially after the founding of the Uniate Church (confirmed with the Union of Brest, in 1596), in the generally Orthodox south-eastern part of Poland-Lithuania ${ }^{3}$.

Bearing in mind the musical culture of the period, it is also worth referring to a notion connected with the Italian perspective. For the inhabitants of the Apennine Peninsula, the Commonwelth was a transalpine country, as was the German Empire, lying on the route along which new artistic trends arising in their country, including new currents in music, were transmitted to the rest of Europe. The principal centres of culture in Poland-Lithuania played a crucial part in the dissemination of these trends across central and northern Europe.

Yet, the Vasa kings of Poland, in particular Zygmunt III (r. 1587-1632) and his son, Władysław IV (d. 1648), were of great service in assuring that the role of the Commonwelth was not confined to the further transmission of a musical repertoire created in Italy to neighbouring countries to the west, east and north. Towards the end of the sixteenth century and particularly during the first half of the seventeenth century, thanks to the patronage of the Vasas, who launched a fashion for Italian culture that also seduced a number of Polish and Lithuanian magnates, an innovative musical output of high quality was produced in Poland-Lithuania by Italian musicians employed there ${ }^{4}$. Composition was practised by the royal maestri di cappella, including Luca Marenzio (1553/ 1554-1599, in Poland-Lithunia 1595-1597/1598), Giulio Cesare Gabussi (d. 1611, at the Polish court 1601-1602), Asprilio Pacelli (d. 1623 in Warsaw, maestro di

2 See Janusz Tazbir, Dzieje polskiej tolerancji [The History of Polish Tolerance], Warszawa 1973, p. 57-70.

3 Cf. Aleksander Jabłonowski, Akademia Kijowsko-Mohylańska. Zarys historyczny na tle rozwoju ogólnego cywilizacji zachodniej na Rusi [Kiev-Mohila Academy. An historical outline against the background of the general rise of western civilisation in Ruthenia], Lwów 1899-1900; Ryszard Łużny, Pisarze kręu Akademii KijowskoMohylańskiej a literatura polska. Z dziejów związków kulturalnych polsko-wschodniostowiańskich XVII-XVIII $w$. [Relations between Writers Associated with Kiev-Mohila Academy and Polish Literature. From the history of cultural ties between Poland and eastern Slavic lands during the seventeenth and eighteenth centuries], in: Zeszyty Naukowe Uniwersytetu Jagiellonskiego [The Scholarly Journals of the Jagiellonian University] nr 142, Prace historycznoliterackie [Works on Literary History] no. 11, Kraków 1966.

4 On Italian musicians at the Polish royal court see Anna and Zygmunt M. Szweykowscy, Wtosi w kapeli królewskiej polskich Wazów [Italians in the Chapel Royal of the Polish Vasa Kings], Kraków 1997; Barbara Przybyszewska-Jarmińska, The History of Music in Poland, vol III: The Baroque, part 1: 1595-1696, trans. John Comber, Warsaw 2002, pp. 57-80. 
cappella to Zygmunt III since 1602), Giovanni Francesco Anerio (d. 1630, in Poland since 1624/1625) and Marco Scacchi (d. 1662, at the Polish royal court c. 1621-1649; chapel-master to Władysław IV since 1632), by other royal musicians (Vincenzo Bertolusi, Giovanni Valentini, Tarquinio Merula among others), by the chapel-master of the vocal-instrumental ensemble of Wawel Cathedral in Cracow, Annibale Orgas (d. 1629 in Poland, in Cracow since 1619), previously prefect of music and chapel-master at the Jesuit Collegium Germanicum in Rome, by musicians employed at magnatial courts in various parts of the Commonwelth, such as the lutenists Diomedes Cato (c. 1555-1628) and Michelangelo (1575-1631, in Poland-Lithuania 1593-1599 and 1600-1606) and Vincenzo Galilei (b. 1609, in the Commonwelth 1631-1647 or longer) - brother and nephew of the great Galileo - and by many others. A prominent place in the history of world opera is due to the court theatre of the Polish Vasa kings (especially Władysław IV), which, in the years 1628-1648, staged at least eleven drammi per musica, the clear majority of which were original works, written to royal commission and prepared by Italians engaged at the court. Almost all the libretti were the work of Virgilio Puccitelli of San Severino in the province of Marche (d. 1654, in Poland-Lithuania c. 20 years, until 1649) secretary to Władysław IV, whilst the music to the majority of these drammi was probably composed by the royal maestro di cappella Marco Scacchi ${ }^{5}$. The scenography, including the mechanisms used to achieve the special effects so essential to Baroque opera, was the work of the Roman Agostino Locci (1601-after 1660 at the court of the Polish kings before 1636, until his death), and clearly predominant among the musicians, especially in the group of singers, were Italians belonging to the royal cappella, who were handsomely remunerated by the king $^{6}$.

A key contribution to European thought on music theory was made in Warsaw by Marco Scacchi, with his classification of music, dividing this art-form into three styles: church, chamber and stage music. The first category was subdivided into four varieties: compositions for 4-8 voices a cappella; polychoral works with organ; vocal-instrumental compositions in concerto; motets in the new style, i.e. stile misto, which combined prima and seconda pratica. In the second category, Scacchi distinguished between madrigals a cappella, madrigals with continuo and compositions for voices and instruments. Finally, the third category comprised recitative either with theatrical gestures or without. Individual works were bound to employ either prima or seconda pratica, depending on the variety. This classification, put forward in the context of the dispute over theory that was carried on during the 1640 s between the royal

5 Documented evidence, however, exists solely in relation to his composition of Il ratto d'Elena, produced in Vilnius in 1636.

${ }^{6}$ Cf. Karolina Targosz-Kretowa, Teatr dworski Wtadystawa IV (1635-1648) [The Court Theatre of Władysław IV (1635-1648)], Kraków 1965; Alina Żórawska, Dramma per musica at the Court of Wtadystaw IV Waza (16271648), article in print; Barbara Przybyszewska-Jarmińska, Dramma per musica at the Court of the Polish Vasa Kings in the Accounts of Foreign Visitors, article in print. 
chapel-master and the organist of St Mary's church in Gdańsk, Paul Siefert (15861666), became accepted and developed in Italy, in the works of Angelo Berardi (1680s), and in Germanic countries remained actual up until the first half of the eighteenth century ${ }^{7}$.

The polemic, documented in extant printed works (above all Scacchi's Cribrum musicum, pub. Venice 1643, and Discorso sopra la musica moderna, pub. Warsaw 1649, and also Examen breve by his supporter, Hieronimus Ninius, pub. Braniewo 1647, and on the other side Siefert's Anticribatio musica, pub. Gdańsk 1645, among others) met with a lively response in the European musical environment. It also contributed to an increased interest at courts and among church ensembles in various centres in central and northern Europe in the compositional output of Marco Scacchi. This interest is testified to by a collection of letters addressed (directly or indirectly) to the chapel-master of the Polish king published by Scacchi as Iudicium Cribri musici (Warsaw, 1649). This publication contained sixteen letters. Ten of the senders were musicians, including renowned composers, led by Heinrich Schütz and - undoubtedly less well-known, but also highly esteemed - Tobias Michael (cantor of St Thomas's church in Leipzig), and musicians of somewhat lesser standing: Laurentius Starck, writing from Anklam, Matthias Rymkovius (then in Vilnius, 1658-72 (cantor in Königsberg), Valentin Thilo of Königsberg, an anonymous correspondent from Stockholm, who referred to Andreas Düben, chapel-master to Queen Christina, David Cracovita (organist of St Mary's church in Toruń) and Krzysztof Werner (cantor of St Catherine's church in Gdańsk), as well as the Silesian musicians Beniamin Ducjus of Opole (then church cantor in Byczyna) and Ambrosius Profius (organist of St Elizabeth's church in Wrocław, known as the author of several anthologies of music in the stile moderno published during the $1640 \mathrm{~s})^{8}$. Almost all requested that Marco Scacchi send them his compositions or indicate how they could be purchased.

There are grounds to surmise that interest in the compositional output of the royal chapel-master soon expanded to encompass musical works written at the Polish court by other composers. Works copied out for the use of various chapels in neighbouring countries, preserved to the present day or else mentioned in inventories of musical items now lost, prove that in the seventeenth century (particularly from the 1640s onwards, most numerously during the

7 Cf. Claude V. Palisca, Marco Scacchi's Defense of Modern Music (1649), in: Words and Music: The Scholar's View. A Mdley of Problems and Solutions Compiled in Honour of A. Tillman Merrit by Sundry Hands, Harvard University, Department of Music 1972, pp. 189-235 (also in: Studies in the History of Italian Music and Music Theory, Oxford 1994); Carl Dahlhaus, "Cribrum musicum". Der Streit zwischen Scacchi und Siefert, in: Norddeutsche und nordeuropäische Musik, ed. Carl Dahlhaus, walter Wiora, in series Kieler Schriften zur Musikwissenschaft, vol. XVI, Kassel, Basel, Paris, London, New York 1965, pp. 108-112; Zygmun M. Szweykowski, Musica moderna w ujęciu Marka Scacchiego [Musica moderna as Understood by Marco Scacchi], Kraków 1977; Michael Heinemann, Der Streit zwischen Marco Scacchi und Paul Siefert (I. Musiktheorie und kompositorische Praxis im protestantischen Deutschland des 17. Jahrhunderts, II. Edition der Texte), in print.

8 See Barbara Przybyszewska-Jarmińska, Recepcja repertuaru kapeli Wtadystawa IV Wazy w świetle "Cribri musicis Marka Scacchiego [The Reception of the Repertoire of the Cappella of King Władysław IV Vasa in Central and Northern Europe in the Light of Iudicium Cribri musici by Marco Scacchi], "Barok«I 1994 nr 2, pp. 95-102. 
second half of that century) copies were being made in various countries of the German Empire (including Upper Hungary - present-day Slovakia - Bohemia and Silesia), as well as in Denmark and Sweden, of works both by Marco Scacchi and also by Polish musicians working in the royal ensemble. With regard to the latter, some gained or extended their training in Italy, as was the case with Franciszek Lilius (d. 1657), son of Vincenzo Lilius (Gigli), one of the first Italian members of the music cappella of Zygmunt III. Probably born in Poland, Franciszek was taught music at the Polish court, then in the 1620 s most probably studied under Girolamo Frescobaldi, living in the maestro's home in Rome ${ }^{9}$. In later years, he was renowned as the chapel-master of the vocal-instrumental ensemble of Wawel Cathedral in Cracow, a composer, and an excellent tutor to young musicians. Meanwhile, Kaspar Förster (1616-1673), of Gdańsk, son of the chapel-master of St Mary's church in that city, is most likely to have commenced his studies under his father, continuing in the years 16331636 under Giacomo Carissimi in Rome's Collegium Germanicum. Subsequently, he was one of the most highly esteemed singers at the court of Władysław IV, and later chapel-master to King Frederick III of Denmark, and briefly also of St Mary's church in Gdańsk ${ }^{10}$. With the biographies of other non-Italian musician-composers employed in the Polish royal chapel we are generally poorly acquainted, especially in respect to their youth. However, one can assume with a high degree of probability that their most important teachers were Italian musicians active at the court. Thanks to the patronage of Zygmunt III, Marco Scacchi, who had arrived in Poland-Lithuania as a young violinist, had the opportunity to deepen his musical training under Giovanni Francesco Anerio, royal chapel-master in the years 1624/1625-1630. Similarly, it was most probably Italian maestri who instructed the Polish royal musicians Bartłomiej Pękiel (d. c 1670) and Marcin Mielczewski (d. 1651), both familiar as composers in central and northern Europe during the seventeenth century. As is shown by extant compositions and musical inventories of seventeenth-century chapels, particular popularity in various centres in central Europe was enjoyed by the compositional output of the latter of the two above-mentioned musicians ${ }^{11}$.

Unfortunately, Marcin Mielczewski's date and place of birth are not known. Also unknown are the circumstances under which he commenced his musical studies, although we do have information that he was a pupil of the aforementioned Franciszek Lilius, most probably either in Warsaw in the late 1620s or else in Cracow at the beginning of the $1630 \mathrm{~s}^{12}$. No later than 1632 he became a

9 Cf. Alberto Cametti, Girolamo Frescobaldi in Roma (1604-1643). Con appendice sugli organi, organari ed organisti della basilica vaticana nel secolo XVII, Milano-Torino-Roma 1908, p. 17.

${ }^{10}$ Cf. Barbara Przybyszewska-Jarmińska, Kacper Förster junior. Zarys biografii [Kacper Förster Junior. A Biographical Sketch], »Muzyka« XXXII 1987 nr 3, pp. 3-19.

${ }^{11}$ Cf. Barbara Przybyszewska-Jarmińska, Marcin Mielczewski - katalog tematyczny utworów [Marcin Mielczewski - A Thematic Catalogue of Works], in: Marcin Mielczewski. Studia, ed. Zygmunt M. Szweykowski, in the series Acta Musicologica Universitatis Cracoviensis VII, Kraków 1999, pp. 27-65.

${ }^{12}$ On the biography of Mielczewski see Barbara Przybyszewska-Jarmińska, Marcin Mielczewski - życie $i$ dorobek [Marcin Mielczewski - His Life and Works], in: Marcin Mielczewski. Studia, op. cit., pp. 7-26. 
musician (speciality not known) of the royal chapel, where he remained until 1644 , earning a reputation above all as a composer of music »for playing and for singing". Around the turn of $1644 / 1645$ he transferred to the court of Władysław IV's brother, Karol Ferdinand Vasa, Bishop of Wrocław and Płock, as maestro di cappella. He remained in the bishop's ensemble until his premature death, before which he managed to draft a will, in which he bequeathed all his compositions to his master - Karol Ferdinand ${ }^{13}$. Although one may assume that his works were used by royal musicians or by the ensemble of Bishop Karol Ferdinand, neither autographs nor even copies of his works written for the needs of these chapels have survived. However, a small number of handwritten copies of Mielczewski compositions prepared on the territory of the Commonwealth of that time immediately following his death are preserved in the Biblioteka Polskiej Akademii Nauk [Library of the Polish Academy of Sciences], in Gdańsk the Biblioteka Warszawskiego Towarzystwa Muzycznego [Library of the Warsaw Music Society] and the Archiwum i Biblioteka Krakowskiej Kapituly Katedralnej [Archive and Library of Cracow Cathedral Chapter] in Poland, and also in the Lietuvos Nacionalinë Martyno Mațvydo Biblioteka [National Library of Lithuania] in Vilnius. In all, these copies represent no more than fifteen percent of the oeuvre of Marcin Mielczewski currently known and preserved, which amounts to around seventy-five compositions. Of these, vocal-instrumental church concertos clearly dominate in quantitative terms, although there are also motets, Masses, both in prima pratica and in concerto, and canzonas for ensemble. The bulk of the Mielczewski legacy was preserved thanks to the interest which this music aroused in countries neighbouring Poland-Lithuania in central Europe.

Testimony to the reputation enjoyed by the Mielczewski oeuvre in the musical circles of this part of Europe is the fact that his solo church concerto Dues in nomine tuo was included alongside compositions by Italian musicians in the printed anthology, prepared by Johannes Havemann, Erster Theil Geistlicher Concerten... (Jena 1659). Meanwhile, the popularity of works by the chapel-master to Karol Ferdinand in Upper Hungary (Slovakia) can be gauged by both the handwritten (mostly unique) copies of his instrumental canzonas preserved in Levoča and also the inventories, compiled towards the end of the seventeenth century, of musical items (now lost) belonging to the cloister chapels of the Piarist fathers in Podolínec and Prievidza ${ }^{14}$. Furthermore, an inventory of copies (now lost) of compositions used in the second half of the seven-

\footnotetext{
${ }^{13}$ See Hieronim Feicht, Przyczynki do dziejów kapeli królewskiej $w$ Warszawie za rzqdów kapelmistrzowskich Marka Scacchiego [Contributions to the History of the Royal Chapel in Warsaw under the Direction of Marco Scacchi], "Kwartalnik Muzyczny« I 1928, nr 1, II 1929 nr 2, reprint in: Hieronim Feicht, Studia nad muzyka polskiego renesansu i baroku [Studies on the Music of the Polish Renaissance and Baroque], joint edition, Kraków 1980, pp. 280-281.

${ }^{14}$ Cf. Jana Kalinayová und Autorenkollektiv, Musikinventare und das Repertoire der mehrstimmigen Musik in der Slowakei im 16. und 17. Jahrhundert, Bratislava 1995; see also Aleksandra Patalas, Polonica winwentarzach stowackich $z$ lat 1581-1718 [Polish Items in Slovakian Inventories from the years 1581-1718], "Muzyka" XIVII 2002 nr 2, pp. 97-107.
} 
teenth century by the Piarist fathers of Stražnice and preserved works by Marcin Mielczewski gathered during that time in Kroměř́z for the chapel of the local bishop, Karl Liechtenstein-Castelcorno, show that his music was also present in Moravia.

On the basis of currently known handwritten copies of Mielczewski compositions, one may judge that one land where they were copied out in particularly great number, and where they also constituted the subject of arrangements testifying to the efforts made to adapt them to local needs, was Silesia. Works preserved in manuscripts of Silesian origins, dating from around the mid seventeenth century, represent over half of the entire extant output of this composer. What is more, the clear majority, belonging to a single collection, which was catalogued as recently as the nineteenth century by Emil Bohn ${ }^{15}$, are furnished solely with the monogram M.M. ${ }^{16}$, which would appear to show that the name of the composer (a long name, which was undoubtedly difficult for anyone not conversant in Polish) was sufficiently familiar and obvious to the copyists most probably associated with the church of St Mary Magdalene in Wrocław that they included it on none of the more than forty manuscripts bearing works by this composer ${ }^{17}$.

The fortunes of history contrived to bring together in Berlin almost all the currently known sources produced in Silesia containing compositions by Marcin Mielczewski, which are now held in the Staatsbibliothek Preussischer Kulturbesitz. Apart from the Bohn collection, which until the Second World War belonged to the Stadtbibliothek in Wrocław (Breslau), the Staatsbibliothek Preussischer Kulturbesitz is also in possession of a Silesian copy in organ tablature notation of the Missa super "O gloriosa Domina", prepared just before the composer's death, and one of the part-books of an earlier compiled (most probably in the same region of Europe) anthology of sacred music (D-Bds Mus. 40073), in which the same Mass was recorded anonymously ${ }^{18}$ (manuscripts

${ }^{15}$ Emil Bohn, Die musikalischen Handschriften des 16. und 17. Jahrhunderts in der Stadtbibliothek zu Breslau, Breslau 1890.

${ }^{16}$ Max Seiffert (Matthiass Mercker. Ein ausgewanderter holländischer Musiker, in: Gedenkboek aaneboden aan Dr. D. F. Schieurleer, Gravenhage 1925, pp. 291-301), with neither biographic arguments nor any evidence based on a critical analysis of style at his disposal, attributed these contributions to Matthias Mercker.

${ }^{17}$ See Barbara Przybyszewska-Jarmińska, Ocalate źródta do historii muzyki w Polsce XVII stulecia ze zbiorów dawnej Stadtbibliothek we Wroctawiu [Extant Sources for the History of Music in Seventeenth-Century Poland from the Collections of the Former Stadtbibliothek in Breslau], "Muzyka" XXXIX $1994 \mathrm{nr}$ 2, s. 3-10; eadem, Nieznany zbiór religijnych utworów wokalno-instrumentalnych Marcina Mielczewskiego [An Unknown Collection of Sacred Vocal-Instrumental Works by Marcin Mielczewski], in: Staropolszczyzna muzyczna. Ksiega konferencji, Warszawa 18-20 października 1996 [Music and Musical Life in Poland during Former Times. The book of conference. Warsaw 18-20 October 1996], ed. Jolanta Guzy-Pasiakowa, Agnieszka Leszczyńska, Mirostaw Perz, Warsaw 1998, pp. 193-214.

${ }^{18}$ A second extant part-book can be found today in the 'Berlin Collection' of the Biblioteka Jagielloniska UJagiellonian Library] (Pl-Kj Mus. 40300). See Zygmunt M. Szweykowski, "Missa sub Concerto" Adama Jarzębskiego, "Muzyka" XIII 1968 nr 4, pp. 28-39; Mirosław Perz, Śladem Adama z Wagrowca (zm. 1629), »Muzyka"XLI 1996 nr 2, p. 6, 12, Barbara Przybyszewska-Jarmińska, Historia w źródtach muzycznych wyeksponowana $i$ ukryta, czyli o siedemanstowiecznych mszach z rękopisów I-Rvat Capp. Sistina 107 oraz D-Bds Mus. 40073 i PL-Kj Mus. 40300 [History Exposed and Concealed in Musical Sources, or on seventeenth-century Mssses from manuscript I-Rvat Capp. Sistina 107 and D-Bds Mus. 40073, and PL-Kj Mus. 40300], »Muzyka« XLVII 2002 nr3-4, pp. 45-61. 
containing two further Mielczewski compositions preserved in the Berlin library, namely Veni Domine and Benedictio et claritas, which belong to the collection of Heinrich Bokemeyer, are of different, later, and most probably north-German origins ${ }^{19}$ ). Of all the Silesian copies of Mielczewski works, only one - a manuscript in part-arrangement containing a copy of the Missa super "O gloriosa Domina' prepared no later than the early 1650s, transferred from Wrocław following the Second World War, is held today in Poland, in the Biblioteka Uniwersytetu Warszawskiego. [Library of the Warsaw University] ${ }^{20}$.

The question arises as to why the oeuvre of Marcin Mielczewski was quite so popular in Silesia. Many answers may be advanced here. One fact of unquestionable significance is that the composer was chapel-master to Karol Ferdinand Vasa, Bishop of Płock (in Mazovia) and of Wrocław (in Silesia), although the physical presence of the composer within the Wrocław diocese (in Nysa, Opole and Wrocław itself) was most probably limited to a few months in 1650. It is highly likely that works bequeathed by the musician to the bishop were played by the chapel of Karol Ferdinand during his Silesian sojourn of almost two years' duration in 1652-1654, i.e. not long after Mielczewski's death. One should also not overlook the interest shown in the music composed at the Polish royal court by Ambrosius Profius, organist of St Elizabeth's in Wrocław, as expressed in letters included by Marco Scacchi in the publication Iudicium Cribri, referred to above, and also confirmed by the publication by Profius of works by the chapel-master to Władysław IV Vasa in his anthologies ${ }^{21}$. It would seem feasible to put forward the hypothesis that compositions by Mielczewski, which were accessible in Silesia thanks to the sojourns of Karol Ferdinand in the Wrocław diocese, and probably even earlier, thanks to the endeavours on the part of Silesian musicians to obtain works from the repertoire of the Italian cappella of the Polish king, were treated there as examples of good musical craftsmanship, as compositions adhering to the Italian stile moderno such as were in great demand at that time in Silesia, composed by a musician trained under the influence of Marco Scacchi and other Italian musicians resident at the court of the Polish Vasa kings.

The sacred works by Marcin Mielczewski, written for performance in Roman Catholic churches, were copied out in Silesia for the needs of Lutheran churches. Due to the differences in doctrine and liturgy between these two confessions, in a number of cases it proved necessary to effect changes in the verbal texts of the works. Extant copies of Mielczewski compositions from the Bohn collection show

${ }^{19}$ See Harald Kümmerling, Katalog der Sammlung Bokemeyer, in series Kieler Schriften zur Musikwissenschaft, vol. XVIII, Kassel-Basel 1970.

${ }^{20}$ Editions of compositions by Marcin Mielczewski in: Marcin Mielczewski, Opera omnia, ed. Zygmunt M. Szweykowski, in: Monumenta Musicae in Polonia, vols. 1-3, Kraków 1976, 1986, 2003. Most of works atributed to Marcin Mielczewski from the Bohn collection ed. Barbara Przybyszewska-Jarmińska, in series Pro Musica Camerata, Warsaw 1996-1999.

${ }^{21}$ See Tomasz Jeż, Kontrafaktury madrygatów w antologiach Ambrożego Profiusa [Contrafacta of Madrigals in the Anthologies of Ambrosius Profius], "Muzyka« XLVII 2002, nr 2, pp. 35-38. 
that they were considered sufficiently 'attractive' for Silesian musicians and congregations for efforts to be made not only to transcribe the works, but also to prepare new texts, texts of German-language contrafacta whose contents differed from the original (the setting of these new words additionally entailed the introduction of certain necessary changes, particularly of a rhythmic nature, to the original musical material). Such alterations were made to several church concertos with Marian texts or devoted to saints. Some works were written out in two versions (the Latin original and the text of the German contrafactum), others (a small number) with only a German text, the original title being indicated in the titular inscription ${ }^{22}$, and in three instances without such information ${ }^{23}$.

One interesting example of the contribution made by both Mielczewski and the musicians who adapted his compositions to local, Silesian needs to the creation of a repertoire that was not only broadly Christian (not exclusively Catholic or Lutheran) but also musically common to the whole of central Europe, since it employed melodic material that was popular in this part of the continent, is the Latin-idiom vocal-instrumental church concerto Audite gentes et exsultate (DBds Mus. Bohn 170, $3^{24}$ ), which is also preserved (anonymously) with the text of the German-language contrafactum Nun höret alle (D-Bds Mus. Bohn 320).

Sizeable fragments of both these compositions are almost exactly convergent with the musical material of the above-mentioned Marcin Mielczewski work, copied out in Silesia on at least three occasions, Missa super »O gloriosa Domina " (2CA2TB, b.c.) ${ }^{25}$. This Mass is based on material from one of the most popular hymns in Poland-Lithuania ${ }^{26}$, O gloriosa Domina, which was sung in a version termed at that time as volgare (known solely from Polish sources) by Polish troops entering battle, and was also familiar and transcribed in a considerable number of other central European countries. Besides manuscripts familiar from the territory of the Commonwealth of Poland and Lithuania ${ }^{27}$, copies of this hymn ${ }^{28}$ can also be found in such sources as the Vietóris-Kódex

${ }^{22}$ For example, the church concerto Ave florum flos Hyacinthe, devoted to the Polish saint Jacek [Hyacinth] Odrowąż, who lived during the Middle Ages, written out with only the text of the German-language contrafactum in the form of the Protestant chorale Nun freud euch Gottes (D-Bds Mus. Bohn 170, 15).

${ }^{23}$ Jesu du bist unser Leben (D-Bds Mus. Bohn 31, 91; 170, 18a; 170, 18b), Jesu meine Freudt und Wonne (D-Bds Mus. Bohn 170, 19) i O seelig ist der Tag (D-Bds Mus. Bohn 170, 34).

${ }^{24}$ Ed. Barbara Przybyszewska-Jarmińska, in series Pro Musica Camerata, Warsaw 1998.

${ }^{25}$ This convergence was pointed out by Tomasz Jasiński (Autorstwo Marcina Mielczewskiego udowodnione. O "berlinskich" koncertach wokalno-instrumentalnych monogramisty M.M. [Proof of the Autorship of Marcin Mielczewski. On the "Berlin"Vocal Instrumental Concertos by the Composer Known under the Monogram M.M.], "Muzyka" XLVIII $2002 \mathrm{nr} 2$, pp. 3-21), who thus provided another very strong argument in support of my attribution of the works signed M.M. to Marcin Mielczewski.

${ }^{26}$ As such, it was included by Jan Aleksander Gorczyn in the first Polish-language music textbook, published in Cracow in 1647, Tabulatura muzyki. Ed. facsimile, on the copy of Czartoryski Library in Cracow, in: Monumenta Musicae in Polonia, ed. Jerzy Morawski, Kraków 1990.

${ }^{27}$ Hieronim Feicht, Marcin Mielczewski -»Missa Super O Gloriosa Domina", in: Ksiega pamiatkowa ku czci Prof. Adolfa Chybinskiego $w$ 70-lecie urodzin [A commemorative book in honour of Professor Adolf Chybinski on his seventieth birthday], Kraków 1950, p. 219.

${ }^{28}$ The variants concern one single melic alteration, and also the metre in which the song is written out. Cf. Maria Pamuła, "Tabulatura muzyki" Jana Aleksandra Gorczyna [The Tablature of Music of Jan Aleksander Gorczyn], »Muzyka« XXII 1977 nr 2, p. 73. 
MUZIKOLOŠKI ZBORNIK • MUSICOLOGICAL ANNUAL XL

(Budapest, Magyar Tudumányos Akadémia Könyvtara, Ms K. 88-8929) and Benedek Szölöszy's cantional Cantus Catholici ${ }^{30}$. To the melody of the 'Polish' version of this hymn (example 1), Mielczewski set the text of the successive sections of the Mass (example 2), but employed this melody, probably earlier, also in the church concerto Audite gentes et exsultate (2CA2TB, 2 vni, 4 tbni, b.c.), linking it, for example, to the following words referring to St John the Baptist: »Hic est praecursor dilectus, et lucerna lucens ante Dominum« (example 3). In the anonymously-preserved copy of this same Mielczewski work (Nun höret alle, 2CA2TB, 2 vni, 4 tbni, b.c.), in the German-language version adapted for performance in Lutheran churches, the melody of O gloriosa Domina has found a new text: »O Himmelreiche Güttigkeit, du grosser Gott von Ewigkeit» (example 4). Thus did this work by a Polish composer, Italian in its technical style, yet by the same token apt to achieve universal appeal during the seventeenth century, employing melodic material sung in various countries of central Europe, but in this version known from Poland-Lithuania only, enter the common repertoire performed in Catholic and Lutheran churches in Silesia - at the very centre of Europe.

\footnotetext{
${ }^{29}$ Ed. Burlas-Fišer-Hořéǰs, Hudba na Slovensku w XVII staroci [Music in Slovakia in the Seventeenth Century], Bratislava 1954.

${ }^{30}$ Ed. as above.
} 


\section{MUZIKOLOŠKI ZBORNIK - MUSICOLOGICAL ANNUAL XL}

Ex. 1: O gloriosa Domina (incl. by Jan A. Gorczyn in: Tabulatura muzyki, Cracow 1647)

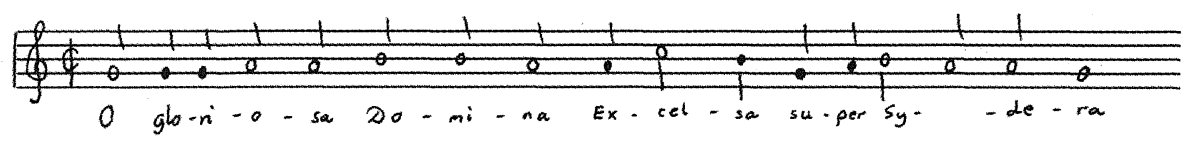

Ex. 2: Marcin Mielczewski: Missa super "O gloriosa Domina”, Kyrie

CI

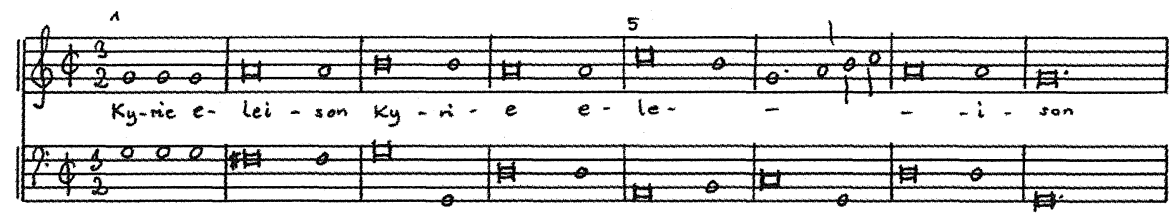

Ex. 3: M. M.: Audite gentes et exsultate

CI

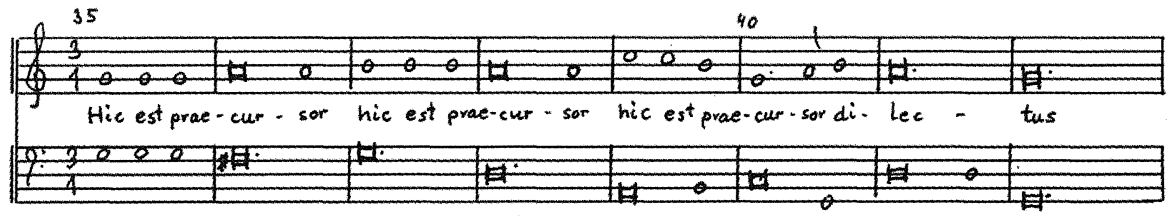

Ex. 4: Anonym: Nun höret alle

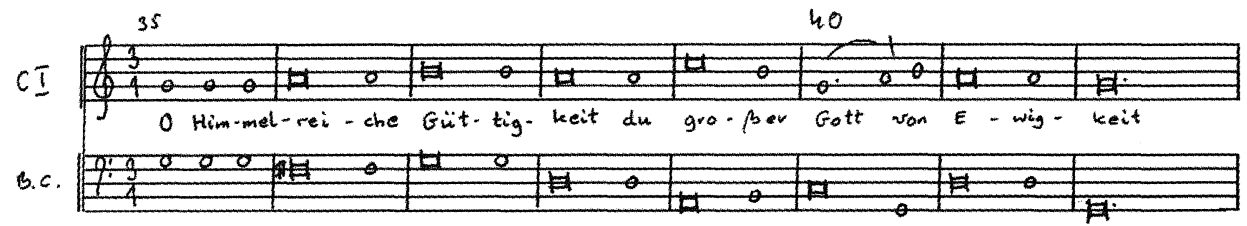

